\title{
The lizard that never sleeps: activity of the pampa marked gecko Homonota uruguayensis
}

\author{
Renata C. Vieira (iD, Laura Verrastro (1), Márcio Borges-Martins (i) \& Jéssica F. Felappi (1)
}

\author{
Departamento de Zoologia, Universidade Federal do Rio Grande do Sul, Av. Bento Gonçalves, 9500, prédio 43435, sala 101, Agronomia, $91501-970$ \\ Porto Alegre, RS, Brazil.
}

Received 12 April 2019

Accepted 24 April 2020

Published 05 June 2020

DOI 10.1590/1678-4766e2020011

\begin{abstract}
It is generally assumed that lizards are active whenever climatic conditions are favorable. Homonota uruguayensis (Vaz-Ferreira \& Sierra de Soriano, 1961) is the only native gecko - and nocturnal lizard - living in the northern Pampa biome, and its ecology is poorly known. This study aimed at describing this species' pattern of daily and annual activity and its relation with environmental temperatures. The study was conducted in the extreme south of Brazil (Rosário do Sul, State of Rio Grande do Sul), between May 2010 and January 2011 at a rocky outcrop located in the Pampa biome. The study was carried out in a total of four seasonal field trips, totalizing 1185 hours of field work. The data were collected, both during the day and the night in 6-hour shifts (duration of the sampling period). The area was randomly covered at each shift to record activity and microhabitat use by the lizards. In total 1541 specimens were recorded throughout the study. Homonota uruguayensis showed diurnal and nocturnal activity in the four seasons, with periods of daily activity varying significantly between all seasons in a cyclic and multimodal pattern, with no significant relation with environmental temperatures. There was no difference in activity related to sex and age classes. Most active lizards were found when air temperatures ranged from 14 ${ }^{\circ} \mathrm{C}$ to $32.9{ }^{\circ} \mathrm{C}\left(82 \%\right.$ of active lizards) and substrate temperatures ranged from $10{ }^{\circ} \mathrm{C}$ to $32.9{ }^{\circ} \mathrm{C}(87 \%$ of active lizards).
\end{abstract}

KEYWORDS. Nocturnal activity; Uruguayan savanna; seasonality; thermal ecology.

RESUMEN. EI lagarto que nunca duerme: actividad del gecko del pampa Homonota uruguayensis. La suposición general ha sido que los lagartos son activos cuando las condiciones climáticas son favorables. Homonota uruguayensis (Vaz-Ferreira \& Sierra de Soriano, 1961) es la única lagartija nativa - y la lagartija nocturna - que vive en el norte de bioma Pampa. La ecología de esta especie es poco conocida y este estudio tuvo como objetivo describir su patrón de actividad diaria y anual y su relación con las temperaturas ambientales. El estudio se llevó a cabo en el extremo sur de Brasil (Rosário do Sul, Rio Grande do Sul), a partir de mayo 2010 - enero 2011, en un afloramiento rocoso situado en el bioma Pampa. El estudio totalizó cuatro excursiones de campo estacionales y 1185 horas. Los datos fueron recogidos a lo largo de los turnos de 6 horas durante el día y la noche. El área fue recorrida aleatoriamente en cada turno siempre registrandose la actividad y el microhabitat utilizado por los lagartos. A lo largo del estudio, 1541 especímenes se registraron. Homonota uruguayensis presentó hábito diurno y nocturno en las cuatro estaciones, con períodos de actividad diaria variando significativamente entre todas las estaciones en forma cíclica y multimodal, no se observó relación significativa con las temperaturas ambientales. No fue constatada diferencia entre los sexos con relación a la actividad y las clases de edad. La mayoría de los lagartos activos fue encontrada a temperaturas del aire que variaron de $14{ }^{\circ} \mathrm{C}$ a $32,9^{\circ} \mathrm{C}(82 \%$ de lagartos activos $)$ y a temperaturas del sustrato entre $10{ }^{\circ} \mathrm{C}$ y $32,9{ }^{\circ} \mathrm{C}(87 \%$ de lagartos activos $)$.

PALABRAS CLAVE. Actividad nocturna; sabana uruguayense; estacionalidad; ecología térmica.

The search for resources and reproductive success are the most important behaviors driving the activity of lizards (Rose, 1981). In general, lizards are active whenever environmental climatic and physical conditions are favorable (Rose, 1981). Activity patterns can be related to diet, foraging and prey capture tactics, thermal ecology, and types of predators (COOPER et al., 2001). Likewise, there is a direct relation between activity and morphology, physiologic capacity, social behavior, reproduction and phylogeny (VITT, 1990; Colli et al., 1997).

Lizards, like many other reptiles, have the ability to regulate and maintain body temperatures in more or less constant thermal ranges making use of environmental heat sources (ANDRADE \& ABE, 2007). Therefore, variation in environmental temperatures affects seasonal activity patterns and may lead to different parameters of life history between species and populations of the same species (ADOLPH \& Porter, 1993; Andrade \& ABe, 2007).

Air and substrate temperatures are the environmental variables that mostly influence the activity of lizards. However, the relative importance of each of these heat sources can vary interspecifically, in accordance to the habitat where the lizard occurs (VAN Sluys, 1992; Bergallo \& Rocha, 1993; HATANO et al., 2001). Lizard activity patterns, spatial use and body temperature are complementary factors and interact in complex ways (PIANKA, 1986).

Lizards' ancestors and the majority of current species are diurnal, but nocturnal activity arose independently several times in the evolutionary history, and geckos are the largest group with nocturnal habits (Gekkonoidea clade, AUTUMN 
\& Nardo, 1995; Autumn, 1999; Autumn et al., 1999). In spite of that, studies on diurnal activity of gekkonids are more common (Pianka \& Pianka, 1976; Evans \& Evans, 1980), and data on nocturnal seasonal activity of geckos are still scarce (TANAKa \& Nishinira, 1987; WeEks \& EspinOza, 2013).

The Homonota genus comprises ten species distributed in southern South America from the Bolivian Chaco to Argentinian Patagonia (Morando et al., 2014). Homonota uruguayensis (Vaz-Ferreira \& Sierra de Soriano, 1961 ) is endemic to the northern portion of the Pampa biome, comprising the southernmost state of Brazil (State of Rio Grande do Sul) and Uruguay (LEMA, 1994). It is a small lizard, with mean snout-vent length (SVL) of $40 \mathrm{~mm}$, restricted to sandstone-basaltic rocky outcrops of the campanha region (Vaz-Ferreira \& Sierra de Soriano, 1973). The high habitat specificity and strong philopatry might be the main reasons for the reduced gene flow and strong genetic structure found among $H$. uruguayensis populations (FELAPPI et al., 2015). Due to the reduced occurrence area and connectivity between populations, the species is classified as vulnerable in the Brazilian list of threatened species (MMA, 2014).

Few studies have investigated the biology of this species. Females lay one or two eggs in communal nests and can produce up to two clutches per reproductive season (GUDYNAS, 1986; ACHAVAL \& OlmOS, 2003). It is a predator with an intermediate strategy between sedentary and active (Achaval \& Olmos, 2003) and is known to display both diurnal and nocturnal activity (CARREIRA et al., 2005), using rocky substrate as shelter (GUdYNAS \& GAMBAROTTA, 1980). However, activity patterns of this species are still poorly known. Due to the strong seasonality of temperatures in its occurrence area, $H$. uruguayensis is expected to show some degree of reduced activity during the colder seasons (autumn and winter) similarly to other lizard species in South Brazil (Liolaemus occipitalis - BuJES \& VerRASTRO, 2008; Tropidurus catalanensis - VIEIRA et al., 2011; Contomastix vacariensis - CARUCCIO et al., 2011).

This study aimed to describe the patterns of daily and seasonal activity of Homonota uruguayensis, searching for variations in diurnal and nocturnal activity levels, as well as for differences related to sex and age classes. Temperature (air and substrate) is expected to be the most important environmental variable affecting activity. Therefore, we also evaluated the strength of this relation.

\section{MATERIALS AND METHODS}

The study was carried out in a locality in the northern portion of the Pampa biome, at the municipality of Rosário do Sul, located in the Midwest region of the state of Rio Grande

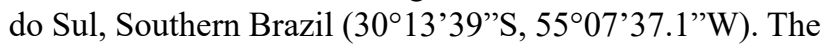
study site is a 4.13 ha private farm called "Fazenda Casa Branca", a rural landscape characterized by the presence of rocky outcrops. The climate in the municipality is humid subtemperate (MALUF, 2000), with mean annual rainfall of 1300-1600 mm, well distributed throughout the year, range of mean annual temperature of $16-20^{\circ} \mathrm{C}$, and well-defined seasons (Wrege, 2012). Maximum altitude in the area is $132 \mathrm{~m}$. The study area has two main vegetation formations: native grasslands (campos) and alluvial deciduous forest (riparian forest) (BOLDRINI, 1997).

The fieldwork was carried out on four expeditions in the autumn (May 2010), winter (July 2010), spring (September 2010) and summer (January 2011), each field expedition lasting 13 days, with a total effort of 1185 hours. Workdays were divided into 6-hour periods: 0:00 h-5:59 h, 6:00 h-11:59 h, 12:00 h-17:59 h and 18:00 h-23:59 h. Data were collected in six work-hours six rest-hours rotations. Thus, it was possible to replicate each rotation six times in each expedition. Since the number of researchers collecting data was not constant throughout the study period (ranging from 3 to 5), we used a capture per unit effort measure (called here "record rate") to standardize the sampling effort $a$ posteriori (adapted from MACIEL et al., 2003). The record rate for each period (hour, day, and season) was calculated as the ratio between the number of lizards and the search effort (in observer-hours) for that same period. The area was randomly covered every shift, and the following data were recorded for each lizard sighted: 1) time of sighting; 2) temperature of the substrate used at the time of the first sighting (Tsb), measured with an infrared surface thermometer with an accuracy of $0.1{ }^{\circ} \mathrm{C} ; 3$ ) air temperature (Ta), measured at $10 \mathrm{~cm}$ from the soil surface at the same point where Tsb was taken, using a digital thermometer with an accuracy of $0.1{ }^{\circ} \mathrm{C}$; and 4) level of activity. Lizard activity at the moment of first sighting was classified as: (1) active - when some kind of activity or movement was registered; and (2) inactive - when immobile or exhibiting little or no reaction (Di-BERnARdo et al., 2007). Whenever possible, sighted specimens were captured, measured (SVL) with a precision caliper of $0.02 \mathrm{~mm}$, and all lizards larger than $27 \mathrm{~mm}$ (SVL) were marked with numbered aluminum rings of $2 \times 4 \mathrm{~mm}$ placed on the thighs.

Age classes were determined as adults or juveniles. Adults were classified according to the minimum reproductive size of the species (smallest reproductive female: $\mathrm{SVL}>35.08$ $\mathrm{mm}$; smallest reproductive male: $\mathrm{SVL}>37.72 \mathrm{~mm}$ ) (Lídia Farias Martins, pers. comm., gonadal variation study). Adult specimens were manually sexed, using a cloacal speculum (ForNASIERO et al., 2007). The variation analysis related to sex and age was made only for captured specimens.

Hourly data were recorded for air temperature (Ta), measured at $10 \mathrm{~cm}$ above the soil surface, and substrate temperature exposed to sun (Tsb). These temperatures were measured under sun exposure and always in the same place. Temperature curves for each season were obtained using the hourly averages of temperatures recorded seasonally. Day length was obtained from the Anuário Interativo of the Observatório Nacional website (MoreIRA, 2012). Relationship between environmental temperatures and record rate of active lizards was tested by simple linear regression (ZAR, 2010). Differences in daily activity between seasons, age classes and sexes (in each season) were tested by the Kolmogorov-Smirnov two-by-two test (SIEGEL, 1975). 
Differences in diurnal and nocturnal activity in each season and between age classes and sexes, were also compared using the Kolmogorov-Smirnov two-by-two test (SIEGEL, 1975), between diurnal activity hours (6:00 h-17:59 h) and nocturnal activity (18:00 h-5:59 h) (ZAR, 2010).

The study was authorized by Instituto Chico Mendes de Conservação da Biodiversidade (License ${ }^{\circ}$. 23534-1). Research protocols employed in the present study were approved by the institutional Animal Care and Use Committee of Universidade Federal do Rio Grande do Sul (registration no. 22977).

\section{RESULTS}

During the study period, 1541 records of Homonota uruguayensis were obtained, 1054 adults (386 males, 387 females and 281 individuals with undetermined sex) and 487 juveniles (Tab. I). Mean female SVL was $40.16 \pm 1.94 \mathrm{~mm}$, mean male SVL was $40.40 \pm 1.42 \mathrm{~mm}$ and mean juvenile SVL was $30.25 \pm 5.41 \mathrm{~mm}$.

Throughout the study, $1007 \mathrm{H}$. uruguayensis individuals were recorded in activity $(65.35 \%), 700$ adults and 307 juveniles, and 534 individuals were recorded inactive (34.65\%), 354 adults and 180 juveniles. During the study period, the record rate was 1.31 lizards/observer-hour and 0.85 lizards/observer-hour when only active animals were considered (Tab. I).

The (monthly, daily, time range) record rates of active lizards were not related to the (monthly, daily, time range) environmental temperatures means (Ta and Tsb); $\left(R^{2}\right.$ active $\mathrm{x}$ $\mathrm{Ta}=0.03 ; R^{2}$ active $\left.\mathrm{x} \mathrm{Tsb}=0.06 ; P>0.05 ; n=23\right)$.

The species was active throughout the entire year; however, it exhibited higher activity rates in the warmer seasons (spring and summer) and lower record rates during the cooler seasons (autumn and winter) $(\mathrm{Dmax}=0.46, \mathrm{P}<0.0001)$ (Tab. I). Homonota uruguayensis displayed a multimodal pattern of daily activity in every season, alternating periods of more or less activity during the day and night. Activity periods varied significantly between all seasons: spring and summer $($ Dmax $=0.19, P<0.05)$, spring and autumn $($ Dmax $=$ $0.16, P<0.05)$, winter and autumn $(\operatorname{Dmax}=0.18, P<0.05)$, winter and summer $(\operatorname{Dmax}=0.19, P<0.05)$ and summer and autumn (Dmax $=0.20, P<0.05)$ (Fig. 1$)$.

In the autumn, the first active lizard was sighted at 0:05 h. The highest record rate occurred around $10 \mathrm{~h}, 15 \mathrm{~h}$ and $20 \mathrm{~h}$ (Fig. 1a); little activity occurred between $4 \mathrm{~h}$ and 5:59 h, and $11 \mathrm{~h}$ and $12 \mathrm{~h}$. The presence of active lizards was recorded in this season, starting with air temperature of $9.6^{\circ} \mathrm{C}$ and under rocks substrate temperature of $10.8^{\circ} \mathrm{C}$. Lower rates of active individuals were recorded in this season.

In winter, lizards were mostly active between 13 and 20:59, and the highest record rate occurred between 14 and 17:59 (Fig. 1b); decreasing records, without the presence of lizards between 21 and 23:59 and between 4 and 5:59. In this study, rates of active individuals with the lowest temperatures were recorded this season. Surprisingly, an active specimen was recorded moving into a gap when temperatures were considered low for reptilian activity ( $\mathrm{Ta}$ $=1.7^{\circ} \mathrm{C}$ and $\mathrm{Tsb}=3.3^{\circ} \mathrm{C}$ ).

In the spring, the first individual was observed at 00:25 $\mathrm{h}$. From this time on, the record rate increased, reaching maximum values between $9 \mathrm{~h}$ and $10: 59 \mathrm{~h}, 13 \mathrm{~h}, 18 \mathrm{~h}$ and $20 \mathrm{~h}$. In the afternoon, there were lower record rates of active individuals at the times with the highest substrate temperatures (between $11 \mathrm{~h}$ and 12:59h, $16 \mathrm{~h}$ and $17 \mathrm{~h}$ ), which can be related to high substrate temperatures (Fig. 1c). The highest seasonal record rates of active individuals were recorded in this season.

In summer, the first active lizard was sighted at 00:07 $\mathrm{h}$, and the peak of record rate occurred around $8 \mathrm{~h}$ and between $19 \mathrm{~h}$ and 20:59 h. In this season, it was observed that high temperatures were not always enough for the species to be active; for example, from $12 \mathrm{~h}$ to $18 \mathrm{~h}$, when temperatures were high, the rates of active lizards were still low.

Comparing diurnal and nocturnal activities between seasons, differences were found in the autumn $(\operatorname{Dmax}=0.41$; $P<0.05)$, winter (Dmax $=0.41 ; P<0.05$ ) and spring (Dmax $=0.45 ; P<0.05)$; diurnal activity was higher than nocturnal activity. Summer was the only season in which diurnal and nocturnal activities were similar ( $\operatorname{Dmax}=0.09 ; P>0.05)$.

Non-significant differences in daily activity between sexes were found in any of the seasons. Grouping the records

Tab. I. Seasonal distribution of records and variation in the activity of Homonota uruguayensis (Vaz-Ferreira \& Sierra de Soriano, 1961) in the study area at Rosário do Sul, Rio Grande do Sul, Brazil, between May 2010 and January 2011 (A, adults; J, juveniles; M, males; F, females; ND, adults whose sex is not determined).

\begin{tabular}{|c|c|c|c|c|c|c|c|c|c|c|c|}
\hline & \multirow{3}{*}{$\begin{array}{l}\text { Search effort } \\
\text { (hours) }\end{array}$} & \multicolumn{5}{|c|}{ Active } & \multicolumn{4}{|c|}{ Inactive } & \multirow{3}{*}{ TOTAL } \\
\hline & & \multirow{2}{*}{$\begin{array}{c}\text { Record } \\
\text { Rate }\end{array}$} & \multicolumn{3}{|c|}{ A } & \multirow{2}{*}{$\mathrm{J}$} & \multicolumn{3}{|c|}{ A } & \multirow{2}{*}{$\mathrm{J}$} & \\
\hline & & & $\mathrm{M}$ & $\mathrm{F}$ & ND & & $\mathrm{M}$ & $\mathrm{F}$ & $\mathrm{ND}$ & & \\
\hline Spring & 369 & 1,19 & 91 & 92 & 71 & 116 & 34 & 26 & 1 & 33 & 464 \\
\hline Summer & 319 & 1,08 & 79 & 92 & 71 & 76 & 8 & 0 & 0 & 2 & 328 \\
\hline Fall & 168 & 0,5 & 33 & 32 & 32 & 71 & 57 & 57 & 28 & 84 & 394 \\
\hline Winter & 151 & 0,62 & 28 & 26 & 53 & 44 & 56 & 62 & 25 & 61 & 355 \\
\hline Total & 1007 & & 231 & 242 & 227 & 307 & 155 & 145 & 54 & 180 & 1541 \\
\hline
\end{tabular}



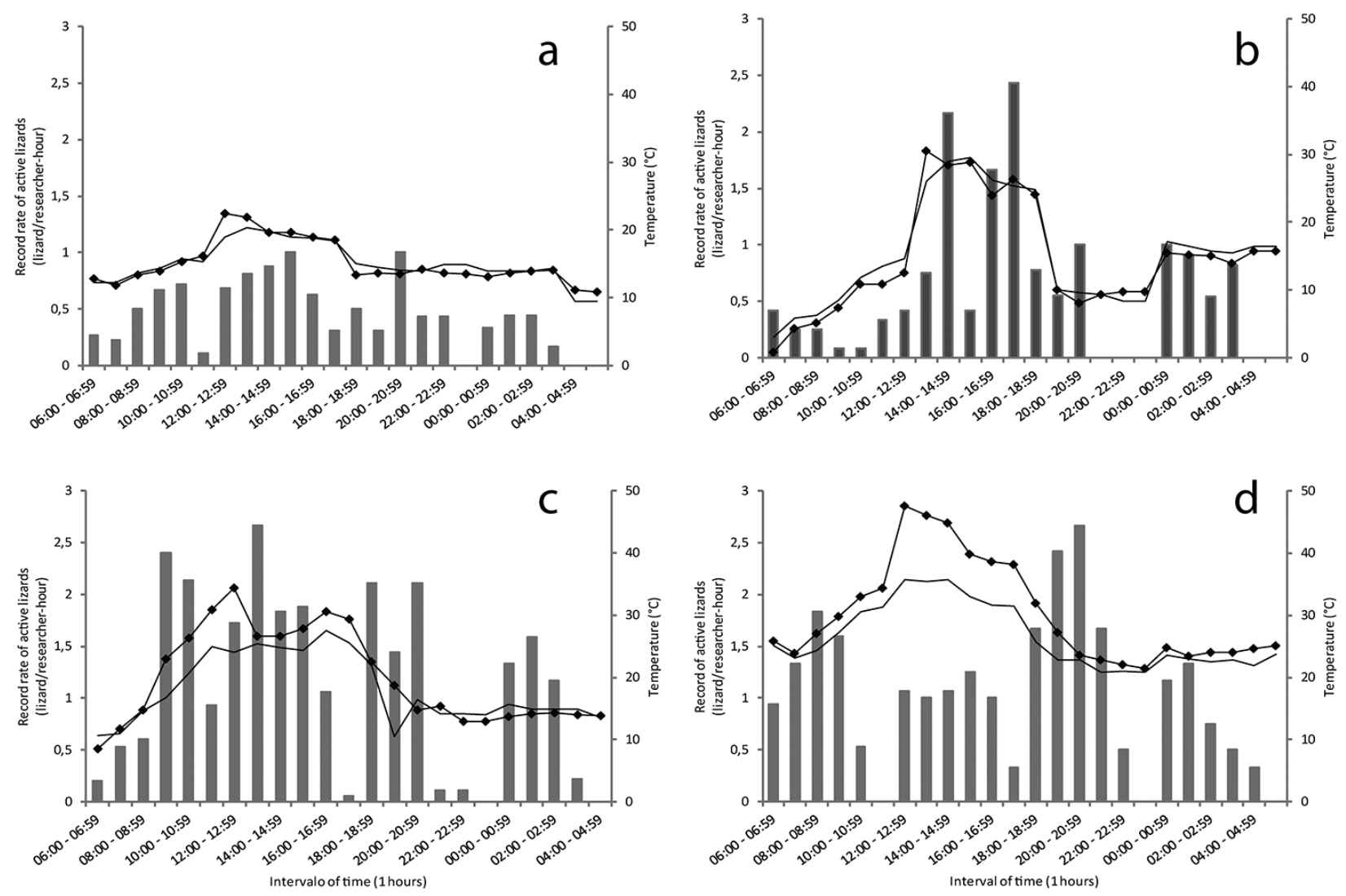

Fig. 1. Daily activity of Homonota uruguayensis (Vaz-Ferreira \& Sierra de Soriano, 1961) (histogram) and hourly means of environmental temperatures (air temperature: solid line, substrate temperature: dotted lines) in autumn (a), winter (b), spring (c) and summer (d) in the study area at Rosário do Sul, Rio Grande do Sul State, Brazil, between May 2010 and January 2011.

of the entire year, activity of males and females did not significantly differ $($ Dmax $=0.05 ; P>0.05)$. Age classes showed similar results, since the activity of adults and juveniles did not significantly differ $(\operatorname{Dmax}=0.06 ; P>0.05)$. When differences between diurnal and nocturnal activities of such groups were analyzed, the data showed significant differences in every case, with a predominance of diurnal activity: diurnal males with nocturnal males (Dmax $=0.30$; $P<0.05)$, diurnal females with nocturnal females (Dmax $=$ $0.19 ; P<0.05)$, diurnal adults with nocturnal adults $(\operatorname{Dmax}=$ $0.31 ; P<0.05)$, and diurnal juveniles with nocturnal juveniles (Dmax $=0.29 ; P<0.05)$.

Most of the active lizards ( $82 \%)$ were found when air temperatures varied from $14{ }^{\circ} \mathrm{C}$ to $32.9{ }^{\circ} \mathrm{C}$ (Fig. 2). Within this interval, the highest frequency of active lizards $(33 \%)$ was recorded when air temperatures ranged from $22{ }^{\circ} \mathrm{C}$ to $27.9^{\circ} \mathrm{C}$. The analysis of Tsb (Fig. 2) reveals that most of the active lizards $(87 \%)$ were found at substrate temperatures ranging from $10{ }^{\circ} \mathrm{C}$ to $32.9^{\circ} \mathrm{C}$, showing a unimodal pattern; the highest frequency of active lizards $(58 \%)$ was recorded when temperatures ranged from $15^{\circ} \mathrm{C}$ to $25.9^{\circ} \mathrm{C}$. Regarding the substrate used by lizards on the first sighting, 728 individuals $(72.34 \%)$ were found under rocks, 254 (25.4\%) inside gaps, 20 (1.98\%) on top of rocks and only five individuals $(0.49 \%)$ were found on the surface or on vegetation.
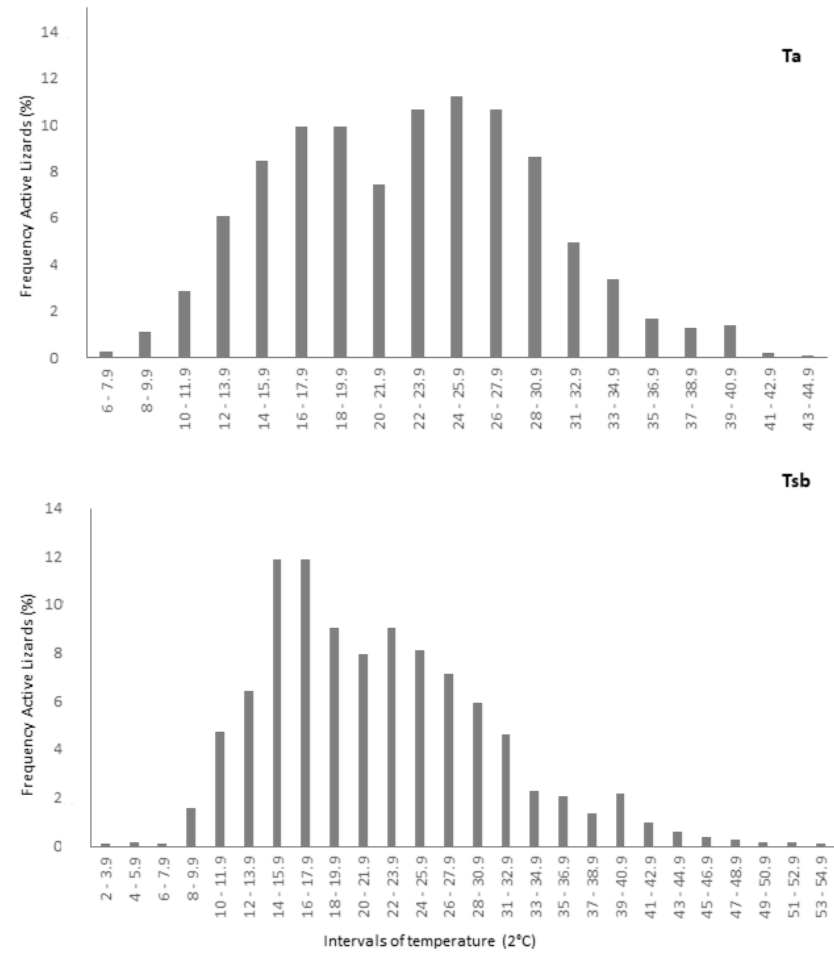

Fig. 2. Relative frequency of active Homonota uruguayensis (Vaz-Ferreira \& Sierra de Soriano, 1961) at different air (Ta) and substrate (Tsb) temperatures $\left(2{ }^{\circ} \mathrm{C}\right.$ intervals $)$ in the study area at Rosário do Sul, Rio Grande do Sul State, Brazil, between May 2010 and January 2011. 


\section{DISCUSSION}

Homonota uruguayensis was active throughout the day and night, with some variation in periods of increased activity and periods of reduced activity (multimodal activity). It is unlikely that all lizards of the same population are simultaneously active when climate or thermal conditions are suitable for activity (Rose, 1981). For example, nocturnal animals are not active the entire night (TANAKA \& NISHIHIRA, 1987). Although activity offers many direct benefits, such as the search for food or partners and the establishment of social connections with other individuals (Rose, 1981), periods of inactivity are of equal importance to survival and to other parameters such as energy conservation (Rose, 1981).

In consequence, why would a species exhibit long periods of diurnal and nocturnal activity in all seasons? Nocturnal lizards are usually considered thigmothermic ectotherms (RENNER, 1998; AUTUMN et al., 1999), displaying both diurnal activity (related to physiological processes, carried out in thermally favorable refuges) and nocturnal activity (related to prey capture, movement and heat loss); (RENNER, 1998). A species showing nocturnal activity would be at a slight disadvantage if compared to a diurnal species, because lower temperatures occur at night, entailing fewer opportunities for thermoregulation (AUTUMN \& NARDO, 1995; ReFinetTi \& SusAlKa, 1997; RenNER, 1998; Autumn et al., 1999). Thus, nocturnal lizards often need to be active at lower temperatures and increase their activity periods (BUSTARD, 1967). Among strictly nocturnal Brazilian lizards, species of the family Gekkonidae, such as Thecadactylus rapicauda, Hemidactylus mabouia and H. palaichthus (VITT \& ZANI, 1997; SILVA \& ARAúJO, 2008), remain active during the entire night, generally foraging close to shelters, as in the case of H. mabouia (HATANO et al., 2001).

The high percentages of active individuals in this population of $H$. uruguayensis $(63.53 \%)$ may reflect the favorable conditions of the environment for obtaining resources. BUSTARD (1967) suggests that geckos have two optimum temperatures, a lower body temperature for foraging at night and a higher body temperature for digestion during the day, which would be reflected in different patterns of diurnal and nocturnal activities, as observed in this study. Additionally, nocturnal gekkonid species, such as Gonatodes humeralis and G. hasemani (VITT et al., 2000), showing diurnal activity are common; thus finding variations that would include both shifts is expected.

The differences of activity found between seasons are something common among lizards (Rose, 1981; HuEY, 1982; AdolPh \& PorTer, 1993; Silva \& ARAúJo, 2008). In warmer seasons (spring and summer), there is an increase in activity rate, while in colder seasons (autumn and winter), there is an increase in inactivity rate and therefore reduced activity (VIEIRA et al., 2011; CARUCCIO et al., 2011). The highest activity rates in spring and summer may be related to the reproductive season and the appearance of hatchlings, since the number of active lizards is usually higher during the reproductive seasons than in non-reproductive seasons
(TANAKA \& NishiHIRA, 1987). H. uruguayensis' reproductive season seems to occur from September to January (Lídia Farias Martins, pers. comm) and time of encounter of eggs and hatchlings (R. Vieira, pers. observ.), which coincides with the seasons (spring and summer) with highest activity rates recorded for the species.

The lowest inactivity recorded was in the summer. For inactivity to occur, activity must have high costs such as high exposure to predators or physiological problems related to excessive heat (Rose, 1981). According to BoGERT (1968), the maximum lethal temperature for reptiles is around $45^{\circ} \mathrm{C}$, under which death occurs shortly after exposure. In the summer of 2011 , Tsb temperatures above $45{ }^{\circ} \mathrm{C}$ were recorded between $12 \mathrm{~h}$ and $15 \mathrm{~h}$, during which there were low activity records.

Finding some individuals active at extremely low temperatures in winter does not seem to be an isolated fact, although it requires further attention. Some species of geckos, such as those of the genus Hoplodactylus in New Zealand, have a marked tolerance to cold and can be found foraging at temperatures below $7{ }^{\circ} \mathrm{C}$ (DAwBIN, 1962). It was also remarked that some species of Homonota, such as H.darwini, can be observed when air temperatures range from $1.4{ }^{\circ} \mathrm{C}$ to $34.5^{\circ} \mathrm{C}$ (RENNER, 1998). This may indicate that these species, rather than having optimal temperatures to be active, would be increasing their efficiency curves, thereby creating a kind of "heat generalism" (HuEY \& KINGSOLVER, 1989; RENNER, 1998), characterized by species that have large temperature curves and are tolerant enough to carry out their activities.

On the other hand, it is important to highlight that temperature is a limiting factor of lizard distribution (SILVA \& ARAúJo, 2008). Across the geographic distribution of geckos, nightly activities cease, and individuals search for shelter when environmental temperatures drop below critical level (BUSTARD, 1967). The occurrence of lizard species in temperate regions requires several adaptations to environments where temperatures are more variable and reach lower values (BUJES \& VerRASTRo, 2006, 2008).

Environmental temperatures had little to no explanation power over activity rates. It is possible that $H$. uruguayensis shows an activity behavior that involves using complex microhabitats (overlapping rocks and gaps) to remain active regardless of environmental temperatures.

The wide variation in the temperature range in which H. uruguayensis appears active $(80 \%$ of the individuals were active at air temperatures between $13{ }^{\circ} \mathrm{C}$ and $30.9{ }^{\circ} \mathrm{C}$ and $87 \%$ of individuals were active between $11^{\circ} \mathrm{C}$ and $32.9^{\circ} \mathrm{C}$ ) seems to coincide with results found for other species of the genus. For example, $H$. darwini can be found active at temperatures below $18{ }^{\circ} \mathrm{C}$ to temperatures above $34{ }^{\circ} \mathrm{C}$ (RENNER, 1998; IBARGÜENGOYTÍA et al., 2007).

Geckos from subtemperate areas have been reported as saxicolous species that use refuges under rocks and gaps; Garthia gaudichaudi in Chile (MARQUET et al., 1990), Phyllodactylus marmoratus in Australia (BUSTARD, 1967), Rhoptropus afer in South Africa (WERNER, 1977) and several species of Homonota (H. uruguayensis, 
Vaz-Ferreira \& Sierra De Soriano, 1973; H. borelli and H. darwini, Cruz et al., 2005; H. darwini, Aguilar \& CRUZ, 2010) and other species from temperate regions, such as Contomastix vacariensis (CARUCCIO et al., 2011) and Tropidurus catalanesis (VIEIRA et al., 2011), use shelters not only for protection from predators but also for foraging activities and thermoregulation (MARQUET et al., 1990).

Thermoregulatory behavior under rocks may be an adaptation for the regulation of metabolic activity, which may also be related to other daily activities (DIAL, 1978). Additionally, observations of activities occurring within gaps are rare (TANAKA \& NisHIHIRA, 1987). However, other lizard species are also active within gaps, such as Xantusia henshawi (LeE, 1974; MAUTZ \& CASE, 1974); one advantage of using this microhabitat for activity, besides reducing the risk of predation, would be limiting water loss by evaporation (DiAL, 1978).

Thus, when demonstrating that $H$. uruguayensis is active over a long period of day and night, in addition to available bibliographies, we can assume that high daytime temperatures would favor digestion, body growth, reproduction and tail regeneration; on the other hand, nocturnal activity is more related to the capture and movement of prey. Further studies are needed to confirm these hypotheses and to determine the possible differences in activities in each period of the day and night, so that we can better understand the biology of this species.

\section{REFERENCES}

Achaval, F. \& Olmos, A. 2003. Anfíbios y Reptiles del Uruguay. Montevideo, Graphis Impresora. 136p.

Adolph, S. C. \& Porter, W. P. 1993. Temperature, activity, and lizard life histories. The American Naturalist 142(2):273-295. doi: $10.1086 / 285538$

Aguilar, R. \& Cruz, F. B. 2010. Refuge Use in a Patagonian Nocturnal Lizard, Homonota darwini: The Role of Temperature. Journal of Herpetology 44(2):236-241. doi: 10.1670/08-270.1

AndRade, D. V. \& ABE, A. S. 2007. Fisiologia de répteis. In: Nascimento, L. B. \& OliveirA, L. B. eds. Herpetologia no Brasil II. Belo Horizonte, Sociedade Brasileira de Herpetologia, p. 171-182.

Autumn, K. 1999. Secondarily diurnal geckos return to cost of locomotion typical of diurnal lizards. Physiological and Biochemical Zoology 72(3):339-351. doi:10.1086/316666

Autumn, K.; Jindrich, D.; Nardo, D. F. DE. \& Mueller, R. 1999. Locomotor performance at low temperature and the evolution of nocturnality in geckos. Evolution 53(2):580-599. doi: 10.2307/2640794

Autumn, K. \& Nardo, D. F. DE. 1995. Behavioral thermoregulation increases growth rate in a nocturnal lizard. Journal of Herpetology 29(2): $157-162$. doi: $10.2307 / 1564552$

Bergallo, H. G. \& Rocha, C. F. D. 1993. Activity patterns and body temperature of two sympatric lizads (Topidurus torquatus and Cnemidophorus ocellifer) with different foraging tatics in Southeastern Brazil. Amphibia-Reptilia 14:312-215. doi: 10.1163/156853893X00525

Bogert, C. M. 1968. How Reptiles Regulate Their Body Temperature. in Vertebrate Adaptations. Scientific American 22:213-221.

BoldRINI, I. I. 1997. Campos do Rio Grande do Sul: Caracterização Fisionômica e Problemática Ocupacional. Boletim do Instituto de Biociências/UFRGS 56:1-39.

Bujes, C. S. \& Verrastro, L. 2006. Thermal biology of Liolaemus occipitalis (Squamata, Tropiduridae) in the coastal sand dunes of Rio Grande do Sul, Brazil. Brazilian Journal of Biology 66(3):945-954.
Bujes, C. S. \& Verrastro, L. 2008. Annual activity of the lizard Liolaemus occipitalis (Squamata, Liolaemidae) in the coastal sand dunes of southern Brazil. Iheringia, Série Zoologia 98(1):156-160.

BustaRD, H. R. 1967. Activity cycle and thermoregulation in the Australian gecko Gehyla variegate. Copeia 1967:753-758.

Carreira, S.; Meneghel, M. \& Achaval, F. 2005. Reptiles de Uruguay. Montevideo, DI.R.A.C., Facultad de Ciencias, Universidad de la República. 639p.

Caruccio, R.; Vieira, R. C.; Verrastro, L. \& Machado, D. M. 2011. Thermal biology, activity, and population parameters of Cnemidophorus vacariensis (Squamata, Teiidae), a lizard endemic to southern Brazil. Iheringia, Série Zoologia, 101(4):283-295. doi: 10.1590/S007347212011000300002

Colli, G. R.; PÉres-Jr, A. K. \& ZatZ, M. G. 1997. Foraging mode and reproductive seasonality in tropical lizards. Journal of Herpetology 31:490-499.

Cooper, W. E. JR; Vitt, L. J.; CALDwell, J. \& Fox, S. F. 2001. Foraging modes of some American lizards: Relationships among measurements variables and discreteness of modes. Herpetologica 57:65-76.

Cruz, F. B.; Kozykariaski, M.; Perotti, M. G.; Pueta, M. \& Moreno, L. 2005. Variación diaria de la temperatura corporal en dos especies de lagartos nocturnos (Squamata, Gekkonidae, Homonota) con comentarios sobre el uso de refugios. Cuadernos de Herpetología 18(2):15-22.

Dawbin, W. H. 1962. The tuatara in its natural habitat. Endeavour 21:1624. doi: 10.1016/0160-9327(62)90129-1

DiAL, B. E. 1978. The thermal ecology of two sympatric, nocturnal Coleonyx (Lacertilia: Gekkonidae). Herpetologica 34(2):194-201.

Di-Bernardo, M.; Borges-Martins, M.; Oliveira, R. B. De \& Pontes, G. M. F. 2007. Taxocenoses de serpentes de regiões temperadas do Brasil. In: Nascimento, L. B. \& Oliveira, E. eds. Herpetologia no Brasil II. Belo Horizonte, Sociedade Brasileira de Herpetologia,. p.222-263.

Evans, P. G. H. \& Evans, J. B. 1980. The ecology of lizards on Praslin Islands, Seychelles. Journal of Zoology 191:171-192. doi: 10.1111/j.14697998.1980.tb01455.x

Felappi, J. F.; Vieira, R. C.; Fagundes, N. J. R. \& VerRastro, L. V. 2015. So Far Away, Yet So Close: Strong Genetic Structure in Homonota uruguayensis (Squamata, Phyllodactylidae), a Species with Restricted Geographic Distribution in the Brazilian and Uruguayan Pampas. PLoS One 10(2): 0118162.

Fornasiero, S.; Atzori, A.; Berti, F.; TAmburini, M.; Cencetti, T. \& ZuFFI, M. 2007. Advances in methodologies of sexing and marking less dimorphic gekkonid lizards: the study case of the Moorish gecko, Tarentola mauritanica. Amphibia-Reptilia 28(3):449-454. doi: https:// doi.org/10.1163/156853807781374719

GuDYNAS, E. 1986. Notes on the behavior of Homonota uruguayensis with special reference to elevated postures (Lacertilia: Gekkonidae). CIPFE CED Orione Contribution in Biology 14:1-10.

Gudynas, E. \& Gambarotta, C. J. 1980. Notes on the ecology of the gekkonid lizard Homonota uruguayensis. ASRA Journal 1(3):13-26.

Hatano, F. H.; Vrcibradic, D.; Galdino, C. A. B.; Cunha-Barros, M.; Rocha, C. F. D. \& Van SluYs, M. 2001. Thermal ecology and activity patterns of the lizard community of the Restinga of Jurubatiba, Macaé, Rio de Janeiro. Revista Brasileira de Biologia 61:287-294. doi: 10.1590/S0034-71082001000200011

HueY, R. B. 1982. Temperature, physiology, and the ecology of reptiles. In: Gans, C. F. \& Pough, H. eds. Biology of the Reptilia. London, Academic Press v. 12, p. 25-91.

HuEY, R. B. \& KingSOLVER, J. G. 1989. Evolution of thermal sensitivity of ectotherm performance. Trends in Ecology and Evolution 4:131-135. doi: 10.1016/0169-5347(89)90211-5

Ibargüengoytía, N. R.; Renner, M. L.; Boretto, J. M.; Piantoni, C. \& Cussac, V. E. 2007. Thermal effects on locomotion in the nocturnal gecko Homonota darwini (Gekkonidae). Amphibia-Reptilia 28:235246. doi: $10.1163 / 156853807780202440$

LEE, J. C. 1974. The diel activity cycle of the lizard, Xantusia henshawi. Copeia 1974:934-940. doi: 10.2307/1442593

Lema, T. 1994. Lista comentada dos répteis ocorrentes no Rio Grande do Sul, Brasil. Comunicações do Museu de Ciências e Tecnologia PUCRS, Série Zoológica 7:41-150.

Maciel, A. P.; Di-Bernardo, M.; Hartz, S. M.; Oliveira, R. B. \& Pontes, G. M. F. 2003. Seasonal and daily activity patterns of 
Liophis poecilogyrus (Serpentes: Colubridae) on the north coast of Rio Grande do Sul, Brazil. Amphibia-Reptilia 24(2):189-200. doi: $10.1163 / 156853803322390435$

MaLuf, J. R. T. 2000. Nova classificação climática do Estado do Rio Grande do Sul. Revista Brasileira de Agrometeorologia 8(1):141-150.

Marquet, P. A.; Bozinovic, F.; Mendel, R. G.; Werner, Y. L. \& JAKSiC, F. M. 1990. Ecology of Garthia gaudichaudi, a gecko endemic to the semiarid region of Chile. Journal of Herpetology 24:431-434. doi: $10.2307 / 1565068$

Mautz, W. J. \& Case, T. J. 1974. The diurnal activity cycle in the granite night lizard, Xantusia henshawi. Copeia 1974:243-251. doi: $10.2307 / 1443030$

MMA - Ministério do Meio Ambiente. 2014. Portaria nº 444 de 17 de dezembro de 2014 que reconhece as espécies da fauna brasileira ameaçadas de extinção. Brasília, MMA.

Morando, M.; Medina, C. D.; Avila; L. J.; Perez, C. H. F.; Buxton, A. \& Sites JR, J. W. 2014. Molecular phylogeny of the New World gecko genus Homonota (Squamata: Phyllodactylidae). Zoologica Scripta 43:249-260 DOI: 10.1111/zsc. 12052.

Moreira, J. L. K. 2012. Anuário Interativo do Observatório Nacional. Available at http://euler.on.br/ephemeris/index.php. Acessed 03.11.2011.

PiANKA, E. R. 1986. Ecology and natural history of desert lizards. Princeton, Princeton University Press. 222p.

Pianka, E. R. \& PianKa, H. D. 1976. Comparative ecology of twelve species of nocturnal lizards (Gekkonidae) in the Western Australian desert. Copeia 1976:125-142. doi: 10.2307/1443783

RefinetTi, R. \& Susalka, S. J. 1997. Circadian rhythm of temperature selection in a nocturnal lizard. Physiology \& Behaviour 62(2):331336. doi: 10.1016/S0031-9384(97)88989-5

Renner, M. L. 1998. Ecofisiología del lagarto nocturno Homonota darwini darwini (Gekkonidae): actividad motriz en relación con la temperatura. Bariloche, Universidad Nacional del Comahue.

Rose, B. 1981. Factors affecting activity in Sceloporus Virgatus. Ecology 62(3):706-716. doi: 10.2307/1937739

Siegel, S. 1975. Estatística não paramétrica para as ciências do comportamento. São Paulo, McGraw-Hill. 350p.
Silva, V. D. N. \& AraúJo, A. F. B. 2008. Ecologia de Lagartos Brasileiros. Rio de Janeiro, Technical Books. 271p.

TANAKa, S. \& Nishinira, M. 1987. A field study of Seasonal, daily, and diel activity patterns of Eublepharis kuroiwae kuroiwae. Herpetologica 43(4):482-489.

VAN SLUYS, M. 1992. Aspectos da ecologia do lagarto Tropidurus itambere (Tropiduridae), em uma área do sudeste do Brasil. Revista Brasileira de Biologia 52(1):181-185.

VAZ-Ferreira, R. \& Sierra de Soriano, B. 1973. Notas ecológicas sobre Homonota uruguayensis. Boletin Sociedad de Zoologia Uruguay 2:53-63.

Vieira, R. C.; Felappi, J. F.; Caruccio, R. \& Verrastro, L. 2011. Population dynamics of Tropidurus torquatus (Wied, 1820) (Squamata, Tropiduridae) in Southern Brazil. South American Journal of Herpetology 6(3):215-222.

VITT, L. J. 1990. The influence of foraging mode and phylogeny on seasonality of tropical lizard reproduction. Papéis Avulsos de Zoologia 37(6):107-123.

VITT, L. J. \& ZANI, P. A. 1997. Ecology of the nocturnal lizard Thecadactylus rapicauda (Sauria: Gekkonidae) in the Amazon region. Herpetologica 53:165-179.

Vitt, L. J.; Souza, R. A.; Sartorius, S. S.; Avila Pires, T. C. S. \& EsPosito, M. C. 2000. Comparative ecology of sympatric Gonatodes (Squamata: Gekkonidae) in western Amazon of Brazil. Copeia 2000(1):83-95.

Weeks, D. M. \& EspinozA, R. E. 2013. Lizards on ice: Comparative thermal tolerances of the world's southernmost gecko. Journal of Thermal Biology 38(5):225-232. doi: https://doi.org/10.1016/j. jtherbio.2013.02.005.

WERNER, Y. L. 1977. Ecological comments on some gekkonid lizards of the Namib Desert, South West Africa. Madoqua 10:157-169.

Wrege, M. S.; SteinmetZ, S.; Reisser Júnior, C. \& Almeida, I.R. DE. eds. 2012. Atlas Climático da região Sul do Brasil: estados do Paraná, Santa Catarina e Rio Grande do Sul. Brasília, Embrapa. 333p.

ZAR, J. H. 2010. Biostatistical analysis. New Jersey, Prentice Hall. 994p. 